\title{
Study on Problems and Strategies of Innovation and Entrepreneurship Education in Colleges
}

\author{
Zhengyu Fan \\ Changzhou College of Information Technology, Changzhou, 213000, China
}

Keywords: College, Innovation and entrepreneurship education, Talent training mode.

\begin{abstract}
As the state overall enhances attention to higher education and actively promotes popularization of higher education, college enrollment scale has expanded gradually in recent years. This facilitates the improvement of talent training quality and has important influence on the development of social construction cause. But it cannot be denied that, the expansion of college enrollment scale also leads to the increase of graduates and the aggravation of competitions. How to cultivate students' innovation and entrepreneurship ability in college education? This has become a key problem that college educators pay attention to. Starting from the problems of implementing innovation and entrepreneurship education by colleges, this paper studies the measures to overall promote innovation and entrepreneurship education, in the hope of improving teaching status and indicating the future direction for students.
\end{abstract}

\section{Introduction}

The rapid development of science and technology gradually brings human into a new development stage. The era of knowledge-driven economy comes therewith. This not just promotes knowledge to become a main element which decides market competitiveness, but also enhances the importance of talents in market competition and drives social reform. Hence, under the new economic situation, it is required to explore educational reform measures step by step, and try to implement innovation and entrepreneurship education guidance. The author hopes college talent training can effectively cope with new social requirements for high-quality talents in the new period and provide effective talent guarantee for social construction in the process of driving college development.

\section{Importance of actively promoting innovation and entrepreneurship education reform}

Under the social background of public entrepreneurship and innovation, colleges actively implement innovation and entrepreneurship education, cultivate students' innovation consciousness and entrepreneurial ability, which has become an inevitable choice of colleges in the process of educational reform and has the crucial influence on healthy growth of college students. Thus, higher education scale of China presents the trend $\mathrm{f}$ continuous expansion. Higher education gradually changes to popular education from elite education. In such case, educational reform in China starts to face multiple contradictions and difficulties. Unreasonable teaching resource allocation, insufficient fund and poor conditions seriously restrict continuous and stable development of some colleges and also limit effective promotion of college talent training ${ }^{[1]}$. From the perspective of talent training, the above problems directly cause that students have no chance to take active part in the practice activity. Their practical ability is poor, and knowledge application ability is insufficient. Meanwhile, their innovation consciousness and creation ability training is greatly limited. The high-quality talents cultivated by colleges are disconnected with social demand for talents. This not just results in the employment difficulty, but also goes against improvement of social construction level. Thus, under the social background of public entrepreneurship and innovation, it is required to correctly cognize the importance of reforming college talent training mode, try to fuse entrepreneurship and innovation 
education in education practice, facilitate optimized development of entrepreneurship and innovation education based on market demand, make sure college talent training can meet national innovative development demand, give correct guidance for students' growth and promote stable development of higher education. So in the new period, colleges must actively promote entrepreneurship and innovation practice and offer strong support for talent training.

\section{Problems of innovation and entrepreneurship education in colleges}

In current stage, colleges have realized the importance of innovation and entrepreneurship education in educational reform, reformed talent training based on the idea of public innovation and entrepreneurship, actively explored the practice of innovation and entrepreneurship education and cultivated students' innovation and entrepreneurship ability ${ }^{[2]}$. But in the practical process of innovation and entrepreneurship, some problems occur due to the lack of systematic theoretical direction. Students' innovation and entrepreneurship ability cannot be improved. Besides, these problems are adverse to students' future development. To be specific, the main problems of college innovation and entrepreneurship education are as follows:

Firstly, innovation and entrepreneurship education fails to gain all-round attention from college education management personnel. In college talent training work, all kinds of courses about innovation and entrepreneurship education are seriously short. Although students can receive proper education and guidance, they cannot form systematic cognition of innovation and entrepreneurship knowledge, which generates certain adverse effect on construction of innovation and entrepreneurship knowledge system and goes against their systematic learning of all types of knowledge.

Secondly, colleges have high requirements for teachers' comprehensive quality in the process of implementing innovation and entrepreneurship education. Teachers should not just own certain specialty accomplishment, but also possess corresponding ability of innovation and entrepreneurship education and can organically combine specialty education with innovation and entrepreneurship education and facilitate students to form innovation and entrepreneurship ability. However, college teachers generally lack the ability of innovation and entrepreneurship education and cannot combine specialty education with innovation and entrepreneurship education. The quality of specialty education, innovation and entrepreneurship education is relatively poor. Moreover, since the time for innovation and entrepreneurship education is short in China, teachers' teaching experience is insufficient, and they lack practice experience. All these are adverse to the improvement of teaching quality and effective promotion of innovation and entrepreneurship education ${ }^{[3]}$.

Thirdly, traditional education form and management method fail to match well with innovation and entrepreneurship education. The interaction between teachers and students is seriously insufficient. Under the action of cramming education, students' learning thought is greatly restricted, which has certain adverse effect on students' systematic study of knowledge. During college education practice in the new period, colleges should combine the detailed requirements of innovation and entrepreneurship education to actively explore educational reform measures, gradually improve current situation of education, improve education quality, effectively promote cultivation of students' innovation and entrepreneurship ability and lay a solid foundation for their future career development.

\section{Effective measures to overall promote innovation and entrepreneurship education reform in college education practice}

Based on actual conditions of college innovation and entrepreneurship education in China, colleges should combine their actual development and specific requirements for innovation and entrepreneurship education to properly adjust teaching activities, enhance the integrating degree of teaching activity and innovation and entrepreneurship education, facilitate improvement of teaching quality, achieve cultivation of students' innovation consciousness and creation ability and create good 
conditions for students' future development ${ }^{[4]}$. Specifically speaking, the methods to overall promote innovation and entrepreneurship education reform in college education practice involve multiple aspects. Different education measures can offer corresponding information guidance for basic educational reform direction, promote teachers to reform and innovate innovation and entrepreneurship education in teaching activities and strive to train students to become high-quality talents.

\section{To innovate talent training mechanism and enhance cultivation of interdisciplinary talents}

In traditional talent training, colleges generally focus on cultivation of students' professional ability, and hope to gradually enhance their mastery of professional knowledge and facilitate their effective employment. But with social development, higher requirements for talents are proposed in the development process of market economy. Enterprises hope to introduce interdisciplinary and advanced talents, which to certain degree forces colleges to reform and innovate talent training work. So in the new period, colleges must focus on reform and innovation of talent training mechanism in the process of innovation and entrepreneurship education, ensure the quality of specialty teaching and actively introduce innovation and entrepreneurship practice education. The author hopes to enhance cultivation of students through innovation and entrepreneurship education, promote improvement of students' innovation and entrepreneurship ability and cultivate students to become high-quality inter-disciplinary talents ${ }^{[5]}$. In the specific teaching practice, college teachers can actively practice “Excellence Program" and "Collaborative Innovation Program”, carry out university-enterprise cooperation teaching, order teaching and sandwich-type teaching activities, and organize multiple forms of innovation and entrepreneurship education practice according to students' future development trend. Colleges may employ excellent teachers and professors to carry out education work to promote cultivation of students' comprehensive quality and offer corresponding guarantee for their development. Only in this way, college innovation and entrepreneurship education can gain the ideal effect, and students' employment competence can be enhanced.

\section{To overall enhance innovation and entrepreneurship course system construction and facilitate students to strength innovation and entrepreneurship ability}

In students' growing process, innovation and entrepreneurship course system construction and teaching method reform can give correct guidance for students to learn professional knowledge and improve their innovation and entrepreneurship ability, and create conditions for their future development. On this basis, relevant college teachers should correctly cognize the importance of innovation and entrepreneurship education and combine the implementation demand of innovation and entrepreneurship education to guide course system construction in educational reform practice. On the one hand, teachers should cognize the importance of ideological and political education for students, try to integrate ideological and political education in innovation and entrepreneurship education, let students accept corresponding thought and form correct world outlook, life outlook and values, and offer corresponding guarantee for students to make correct employment choice after their graduation $^{[6]}$. Meanwhile, at the level of ideological education, teachers should guide students to firmly establish entrepreneurship awareness, optimize and integrate campus and off-campus resources of innovation and entrepreneurship education, reform classroom teaching activities, facilitate exertion of guiding function of innovation and entrepreneurship education and lay the foundation for students' future development. On the other hand, it is required to properly adjust specialized course teaching, introduce cutting-edge contents of domestic and overseas innovation and entrepreneurship education events, actively introduce scientific innovation cases on the basis of imparting professional knowledge, achieve cultivation of innovative thinking and entrepreneurial ability, let students grasp certain learning experience in the process of learning professional knowledge, motivate their innovation inspiration and create good conditions for cultivating students to become high-quality talents. Only in this way, colleges can actively change traditional teaching mode, abandon wrong teaching idea and thought, make sure innovation and entrepreneurship education can be combined with social demand for talents, optimize innovation and entrepreneurship 
education based on the market, facilitate the exertion of functions of innovation and entrepreneurship education, effectively supervise and guide students' healthy growth, drive students' personal development and offer talent guarantee for socialist modernization construction.

\section{To actively construct undergraduate innovation and entrepreneurship incubator}

In educational reform practice, colleges should make the best of schoolfellow resources and social idle funds to implement innovation and entrepreneurship education, enhance construction of undergraduate innovation and entrepreneurship incubator, provide students with the chance to participate in innovation and entrepreneurship education practice and promote final formation of innovation and entrepreneurship practice ability. In the aspect of specific operation, colleges should introduce construction funds from multiple channels, appropriate certain area of space in campus and enhance construction of undergraduate innovation and entrepreneurship incubator. Meanwhile, during construction of undergraduate innovation and entrepreneurship incubator, it is required to fully explore characteristic specialty, guide students to participate in enterprise incubation, and guide students' office management. In this way, the author hopes to create conditions for students to join in innovation and entrepreneurship practice and gain fine practice experience, effectively improve the quality of innovation and entrepreneurship education and enhance students' innovation and entrepreneurship ability. At the same time, after the innovation and entrepreneurship incubator is built, innovation and entrepreneurship practice platform should be built on campus. As well, professional teachers should be introduced to carry out professional education and guidance for students so as to strengthen scientificity and systematicness of innovation and entrepreneurship education and provide guarantee for cultivating students to become high-quality interdisciplinary talents $^{[7]}$. Only in this way, colleges can really offer the practice platform for students to join in innovation and entrepreneurship activities, and scientificity and systematicness of innovation and entrepreneurship education can be further highlighted. Meanwhile, students can feel the hardships of starting business and joys of success in the innovation and entrepreneurship incubator, form more systematic cognition of innovation and entrepreneurship and more prudently choose whether to participate in innovation and entrepreneurship after their graduation. Additionally, they can analyze and solve problems overall during participating in innovation and entrepreneurship as well as promote the increase of success rate.

\section{Conclusion}

Under the background of public entrepreneurship and innovation, reform and innovation of college education and teaching have become the key content of college educational reform. It is also a main development direction of college talent training reform and innovation. Active implementation of innovation and entrepreneurship education in college talent training work can reinforce cultivation of students' innovation and entrepreneurship ability, facilitate gradual improvement of their employment competence, give correct guidance of students' future development, and play a crucial role in relieving employment pressure. Therefore, it is required too overall analyze the measures of innovation and entrepreneurship education and offer solid guarantee for smooth implementation of educational reform.

\section{References}

[1] Zhang Zhanguo, Problems and Countermeasures of Innovation and Entrepreneurship Education in Local Colleges, Journal of Beihua University(Social Sciences), 2014, 15(5):142-144.

[2] Xu Shan, Chen Kaibing, Problems and Countermeasures of Innovation and Entrepreneurship Education in Local Colleges, Finance Theory and Teaching, 2016(5):93-95. 
[3] Xiao Han, Zhu Mintian, Study on Problems and Countermeasures of Innovation and Entrepreneurship Education in Local Colleges under the Situation of "Public Entrepreneurship and Innovation”, Economic Research Guide, 2017(11):57-59.

[4] Yu Changying, Xu Yumei, Lv Wenhao, Necessity and Strategy for Colleges to Implement Innovation and Entrepreneurship Education, Construction and Budget, 2016(8):42-45.

[5] Zhai Xibao, Study on Problems and Countermeasures of Innovation and Entrepreneurship Education in Local Colleges - Based on Questionnaire Analysis of Colleges in Shandong Province, Qingdao University, 2015.

[6] Liu Xunda, Study on Problems and Countermeasures of Innovation and Entrepreneurship Education in Local Colleges, Guide for Knowledge Seeking, 2016(24):47-48.

[7] Huang Lijuan, Analysis on Problems and Improvement Countermeasures of Innovation and Entrepreneurship Education in Chinese Colleges, Net Friend World Cloud Education, 2014(13):285-286. 